\title{
Aspects of Meaning in the Hortatory Discourse: A Semantic Overview
}

\author{
Hilda Hilaliyah ${ }^{1}$, Puji Anto ${ }^{2}$ \\ \{hilda.unindra@gmail.com ${ }^{1}$, pujianto@unindra.ac.id ${ }^{2}$ \} \\ Universitas Indraprasta PGRI, Jakarta, Indonesia ${ }^{12}$
}

\begin{abstract}
Hortatory discourse aims to influence readers. As the other forms of discourse, the meaning of a hortatory discourse will be easily grasped when the reader is able to understand the aspects of meaning contained in it. Using Palmer's theory, this study aims to identify the aspects of meaning in hortatory discourse that can facilitate the reader in understanding the conveyed meaning. This study uses a qualitative descriptive approach with a documentation method. The research object is @ dewopakde's Instagram posts. The results of this study indicate that there are aspects of sense, feeling, tone, and intention that are interrelated to each other so that the reader can understand the meaning of the posts. The posts also contain classification of statements that are persuasive and narrative. Thus, the meaning that the writer wants to convey can be understood by the reader.
\end{abstract}

Keywords: Aspects of meaning, Hortatory discourse, Palmer's theory, Semantics

Aspek Makna dalam Diskursus Hortatori: Sebuah Tinjauan Semantik

\begin{abstract}
Abstrak. Wacana hortatori bertujuan untuk memengaruhi pembacanya. Sebagaimana pada bentuk-bentuk wacana lain, makna pada sebuah wacana hortatori akan mudah dicerap ketika pembaca mampu memahami aspek makna yang terdapat di dalamnya. Dengan menggunakan teori Palmer, penelitian ini bermaksud mengidentifikasi aspekaspek makna dalam wacana hortatori yang dapat memudahkan pembaca dalam memahami makna yang disampaikan. Penelitian ini menggunakan pendekatan deskriptif kualitatif dengan metode dokumentasi. Objek penelitian yang digunakan adalah unggahan Instagram @ dewopakde. Hasil dari penelitian ini menunjukkan bahwa terdapat aspek pengertian, perasaan, nada, dan tujuan yang saling berkaitan sehingga pembaca dapat memahami makna di dalam unggahan tersebut. Unggahan tersebut pun memuat klasifikasi pernyataan yang bersifat persuasif dan naratif. Dengan demikian, makna yang ingin disampaikan penulis dapat dipahami oleh pembacanya.
\end{abstract}

Kata kunci: Aspek makna, Wacana hortatori, Teori Palmer, Semantik

\section{Pendahuluan}

Bahasa merupakan sarana komunikasi yang digunakan oleh makhluk sosial untuk berinteraksi, baik berupa ucapan, pikiran, maupun perasaan [1]. Bahasa dapat berwujud 
wacana, yakni suatu kesatuan yang amat luas dan lengkap serta harus memiliki unsur kohesi dan koherensi yang berguna untuk memudahkan pembaca memahami sebuah wacana [2]. Sebuah wacana akan sulit dimengerti ketika pembaca belum mampu memahami aspek makna yang terdapat di dalamnya. Salah satu jenis wacana, yang hendak didiskusikan di dalam tulisan ini, adalah wacana hortatori.

Wacana hortatori merupakan tuturan yang berisi ajakan atau nasihat, termasuk ekspresiekspresi yang memperkuat keputusan agar lebih meyakinkan. Wacana tersebut digunakan untuk mengajak pendengar atau pembaca agar terpikat dengan pendapat yang dikemukakan. Isinya selalu berusaha membawa pembaca untuk menyetujui pendapat dengan contoh, bentukbentuk perbandingan, uraian kronologis, dan identifikasi dengan orientasi terperinci mengenai materi yang dijelaskan [3]. Dengan kata lain, wacana hortatori digunakan untuk memengaruhi pendengar atau pembaca; Sifatnya persuasif dan tujuannya adalah mencari pengikut/penganut yang bersedia melakukan, atau paling tidak menyetujui, pendapat yang disampaikan dalam wacana tersebut [4].

Penelitian tentang wacana hortatori sudah banyak dilakukan. Setiyanto telah melakukan penelitian untuk mengungkap slot dan struktur slot dalam berbahasa Jawa dengan menggunakan metode agih teknik lesap, substitusi, dan permutasi [5]. Adapun Indiyastini memfokuskan penelitiannya pada paragraf hortatori dalam bahasa Jawa [6]. Kedua penelitian tersebut menggunakan teori struktural sebagai alat analisisnya dan objek kajiannya berupa wacana hortatori yang ada dalam buku dan majalah.

Kendati penelitian tentang wacana hortatori sudah cukup banyak, namun penelitian tentangnya di media sosial masih cukup jarang. Oleh karena itu, sangat menarik untuk mengkaji wacana hortatori di media sosial, terlebih mempertimbangkan betapa maraknya penggunaan media sosial saat ini. Teori aspek makna menurut Palmer sangat relevan untuk keperluan ini, karena dapat mengungkap makna dalam wacana hortatori dengan mengedepankan aspek linguistik kebudayaan. Dengan kata lain, teori tersebut relevan untuk menyelidiki aspek bahasa dan budaya.

Media sosial sangat lekat dengan kehidupan dan kebudayaan kontemporer; bahasa sekalipun dipaksa untuk berjalan beriringan dengan perkembangan termutakhir peradaban manusia tersebut. Banyak sekali platform media sosial yang lazim digunakan, seperti Facebook, Twitter, WhatsApp, Instagram, dan lain-lain. Di antara media-media sosial tersebut, Instagram termasuk yang paling banyak digunakan. Indonesia menempati posisi ketiga pengguna Instagram tertinggi, setelah Amerika Serikat dan Brazil, menurut We Are Social. Pengguna Instagram di Indonesia mencapai 53 juta pengguna, dengan persentase 49\% wanita dan 51\% laki-laki [7].

Besarnya penggunaan platform media sosial Instagram berpengaruh pada masifnya informasi, baik yang disampaikan maupun yang diterima. Besarnya penggunaan inilah, di samping banyaknya wacana hortatori yang dapat dijumpai pada unggahan Instagram, pertimbangan-pertimbangan utama untuk menjadikan Instagram sebagai objek kajian pada studi ini. Kepopuleran Instagram tidak terlepas dari karakteristiknya yang menggunakan foto sebagai alat komunikasi, sehingga memungkinkan penggunanya menciptakan galeri pribadi. Instagram memberikan ruang untuk berbagi dan berinteraksi, serta menampilkan diri dan membentuk apa yang ingin disampaikan kepada khalayak melalui foto atau video.

Sebagai studi kasus, penulis memilih unggahan Instagram Pramono Dewo, yang dikenal melalui akun Instagramnya: @dewopakde. Pramono Dewo bukanlah seorang selebritis, melainkan pengusaha sukses yang aktif di Instagram dengan menampilkan unggahanunggahan kata-kata motivasi yang menyentuh hati dan dekat dengan kehidupan sehari-hari. Inilah yang menjadi pembeda dari unggahan lain yang hanya menampilkan aktivitas 
keseharian sebagai bentuk ekspresi diri. Pramono Dewo merupakan suami dari Yuanita Rohali dan ayah dari penyanyi Karis Alika Islamadina. Unggahan pada akun @ dewopakde syarat dengan wacana hortatori. Tidak semua yang disampaikan dalam unggahan tersebut dapat dengan mudah dipahami oleh masyarakat. Oleh sebab itu, studi ini mencoba mengungkap makna wacana hortatori dalam unggahan tersebut dengan pendekatan linguistik kebudayaan menurut Palmer.

\section{Metode Penelitian}

Penelitian ini menggunakan pendekatan deskriptif kualitatif dengan metode dokumentasi. Pendekatan tersebut bertujuan untuk mendeskripsikan suatu peristiwa yang sedang terjadi yang di dalamnya terdapat upaya untuk mencatat, menganalisis, dan menginterpretasikan kondisi-kondisi yang ada. Subjek dari penelitian ini adalah unggahan Instagram di akun @ dewopakde, sedangkan objek penelitiannya wacana hortatori dalam unggahan tersebut yang bertemakan kehidupan. Wacana hortatori dalam unggahan tersebut kemudian dianalisis dengan teori Palmer, meliputi aspek pengertian (sense), perasaan (feeling), nada (tone), dan tujuan (intention).

\section{Hasil dan Pembahasan}

Untuk mengungkap makna dalam teks yang tertuang dalam media apa pun harus ada pemahaman yang baik terkait konsep semantik. Semantik adalah bagian dari struktur bahasa yang berhubungan dengan makna ungkapan dan struktur makna suatu wicara. Makna adalah maksud pembicaraan, pengaruh satuan bahasa dalam pemahaman persepsi, serta perilaku manusia atau kelompok [8]. Sejalan dengan itu, Kroeger berpendapat bahwa istilah semantik kerap didefinisikan sebagai pengkajian makna, namun nampaknya lebih akurat jika didefinisikan sebagai pengkajian terhadap hubungan antara bentuk linguistik dan makna, sebagaimana pernyataannya di bawah ini:

"The term semantics is often defined as the study of meaning. It might be more accurate to

define it as the study of the relationship between linguistic form and meaning. This

relationship is clearly rule-governed, just as other aspects of linguistic structure are." [9]

Di sisi lain, Pateda mengemukakan bahwa istilah makna merupakan istilah yang membingungkan. Makna selalu menyatu pada tuturan kata maupun kalimat [10], berupa maksud atau pengertian yang disampaikan oleh penutur kepada petutur melalui seperangkat bunyi atau simbol sebuah bahasa sesuai dengan aturan dan aturan kebahasaan [11].

Dilthey berpendapat bahwa untuk memahami suatu teks, kita harus menempatkannya di dalam konteks kehidupan penulisnya, di mana konteks kehidupan sendiri mencakup masyarakat, kebudayaan, dan sejarah. Namun, makna sesungguhnya merupakan isi yang terkandung di dalam suatu bentuk atau lambang, yaitu hubungan antara lambang atau satuan bahasa dengan dunia luar yang disepakati bersama oleh para pemakai bahasa sehingga dapat saling mengerti [12]. Dengan kata lain, mempelajari makna kata pada hakikatnya berarti mempelajari bagaimana para pemakai bahasa dalam suatu masyarakat menafsirkan lambanglambang bahasa untuk dapat saling mengerti. Salah satu media untuk menyampaikan maksud adalah dengan menggunakan tulisan [13]. 
Makna di dalam ujaran bahasa sebenarnya sama saja dengan makna yang ada dalam sistem lambang atau sistem tanda lainnya karena bahasa sesungguhnya juga merupakan suatu sistem lambang. Hanya saja makna dalam bahasa diwujudkan dalam lambang-lambang yang berupa satuan-satuan bahasa, yaitu kata/leksem, frase, kalimat, dan sebagainya [14]. Makna dapat pula ditinjau dari pendekatan analitis atau referensial, yakni mencari esensi makna dengan cara menguraikannya atas unsur-unsur utama. Pendekatan tersebut berbeda dengan pendekatan operasional yang mempelajari kata dalam penggunaannya-menekankan bagaimana kata secara operasional [15].

Aspek-aspek makna mempunyai pengaruh terhadap jenis-jenis makna yang ada dalam semantik. Salah satunya makna referensial. Makna referensial menurut Palmer adalah hubungan antara unsur-unsur linguistik berupa kata-kata dan kalimat-kalimat dengan dunia pengalaman non-linguistik. Referen atau acuan adalah sesuatu yang ditunjuk oleh suatu lambang. Makna referensial merupakan makna yang langsung menunjuk pada sesuatu, baik benda, gejala, kenyataan, peristiwa, maupun proses [10]. Dengan kata lain, makna referensial dapat diartikan sebagai makna yang langsung berhubungan dengan acuan yang ditunjuk oleh kata atau ujaran. Ini berarti bahwa makna referensial dekat hubungannya dengan dunia luar bahasa, baik berupa objek konkret maupun gagasan, yang dapat dijelaskan melalui analisis komponen.

Aspek makna berdasarkan teori Palmer dapat memudahkan dalam memahami makna yang ada. Aspek makna ini berdasarkan fungsi dapat dibedakan atas "pengertian" (sense), "perasaan" (feeling), "nada" (tone), dan "tujuan" (intention) [16]. Aspek pengertian dapat dicapai apabila antara pembicara/penulis dan pendengar/pembaca berbahasa sama. Pengertian disebut juga dengan tema, yang melibatkan ide atau pesan yang dimaksud. Aspek perasaan berhubungan dengan sikap pembicara dalam situasi pembicaraan. Dalam mewujudkan aspek makna tersebut, digunakan kata-kata yang sesuai situasinya. Aspek nada merujuk pada sikap penulis terhadap pembaca. Aspek makna ini melibatkan pembicara untuk memilih kata-kata yang sesuai dengan keadaan lawan bicara dan pembicara sendiri. Hubungan pembicarapendengar menentukan sikap yang akan tercermin di dalam kata-kata yang digunakan. Aspek nada berhubungan pula dengan aspek perasaan. Adapun aspek tujuan melibatkan klasifikasi pernyataan yang bersifat deklaratif, persuasif, naratif, politis, atau pedagogis (pendidikan).

Selanjutnya, akan dijelaskan temuan penelitian yang diambil dari akun Instagram @ dewopakde. 


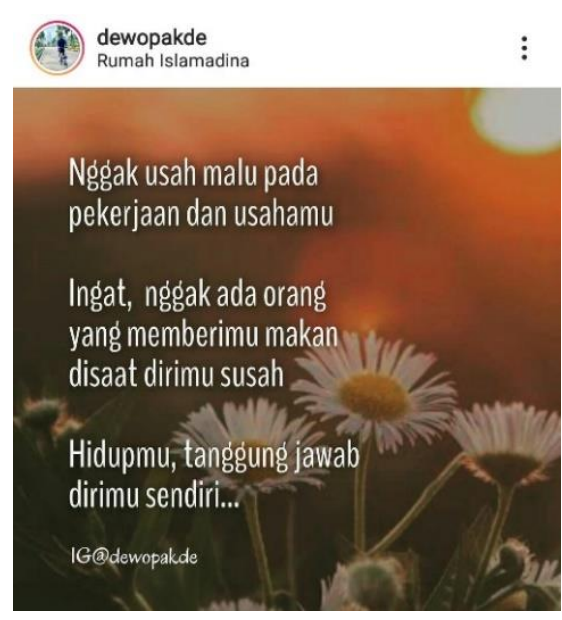

Gambar 1. Wacana Hortatori 1 [17]

Pada gambar 1 tampak adanya pengertian yang menunjukkan adanya penyampaian motivasi kepada pembaca berkaitan dengan kehidupan yang realistis. Hal ini tampak pada kalimat "Nggak usah malu pada pekerjaan dan usahamu. Ingat, nggak ada orang yang memberimu makan di saat dirimu susah. Hidupmu, tanggung jawab dirimu sendiri." Artinya, pembaca diminta untuk terus bersemangat menghadapi hidup. Perasaan yang tampak dari unggahan tersebut adalah perasaan semangat yang berusaha dimunculkan oleh penulis, sehingga pembaca turut berpikir bahwa hidup ini adalah tanggung jawab diri sendiri, bukan orang lain. Nada yang muncul dari unggahan tersebut adalah nada santai dan mendalam, sehingga pembaca terbawa pada suasana yang ada. Adapun tujuan pada unggahan ini berbentuk persuasif, karena mengajak pembaca untuk tetap bersemangat, berjuang, dan bertanggung jawab terhadap diri sendiri.

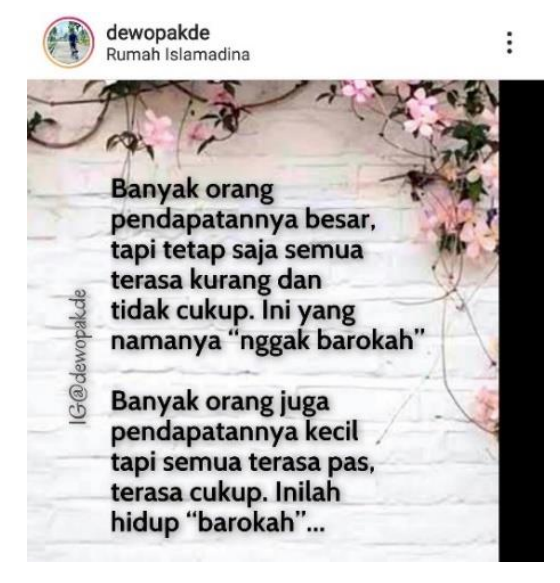

Gambar 2. Wacana Hortatori 2 [17]

Pada gambar 2 tampak adanya pengertian yang memberikan sebuah pandangan kepada pembaca berkaitan dengan keberkahan hidup. Hal ini tampak pada kalimat 'Banyak orang 
pendapatannya besar, tapi tetap saja semua terasa kurang dan tidak cukup. Inilah yang namanya "nggak barokah". Banyak orang juga berpendapatan kecil tapi semua terasa pas, terasa cukup. Inilah hidup "barokah”...' Artinya, pembaca diminta untuk selalu bersyukur dan tidak berkecil hati jika pendapatannya kecil. Bisa jadi pendapatan kecil, tetapi berkecukupan (berkah). Sebaliknya, bisa jadi juga pendapatan besar tetapi selalu tidak tercukupi (tidak berkah). Perasaan yang tampak dari unggahan tersebut adalah selalu optimis dan bersyukur atas apa yang didapatkan dari Sang Pencipta. Nada yang muncul dari unggahan tersebut adalah nada satire. Yang terpenting adalah pembaca diarahkan untuk tidak selalu berorientasi pada pendapatan yang besar. Adapun tujuan pada unggahan ini berbentuk persuasif karena mengajak pembaca untuk selalu bersyukur dan mengharap keberkahan di dalam hidupnya.

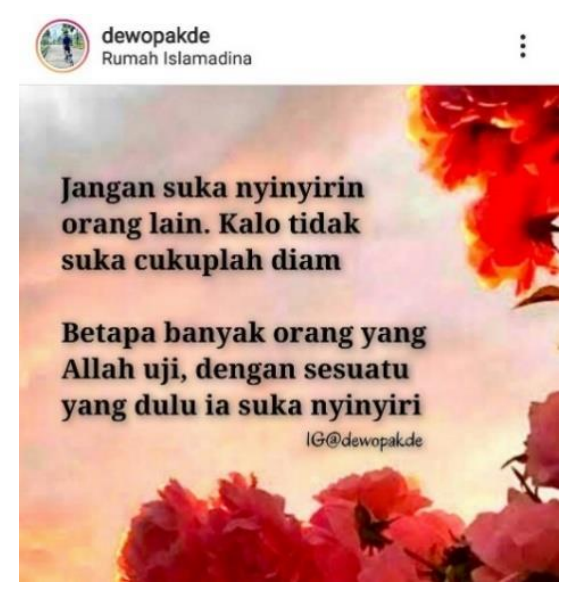

Gambar 3. Wacana Hortatori 3 [17]

Pada gambar 3 tampak adanya pengertian yang menunjukkan sebuah pesan kepada pembaca berkaitan dengan bersikap dan bertingkah laku dalam hidup. Hal ini tampak pada kalimat "Jangan suka nyinyirin orang lain. Kalo tidak suka, cukuplah diam. Betapa banyak orang yang Allah uji dengan sesuatu yang dulu ia nyinyiri." Artinya, pembaca diminta untuk berhati-hati di dalam bertingkah laku, terutama dalam menyikapi hal yang selalu dinyinyiri. Jika memang tidak menyukai, lebih baik diam karena bisa jadi hal tersebutlah yang ada pada diri orang tersebut. Perasaan yang tampak dari unggahan tersebut adalah perasaan berhati-hati dalam bersikap dan bertingkah laku. Nada yang muncul adalah nada mengingatkan. Adapun tujuan pada unggahan ini berbentuk persuasif karena mengajak pembaca untuk tidak nyinyir kepada orang lain. 


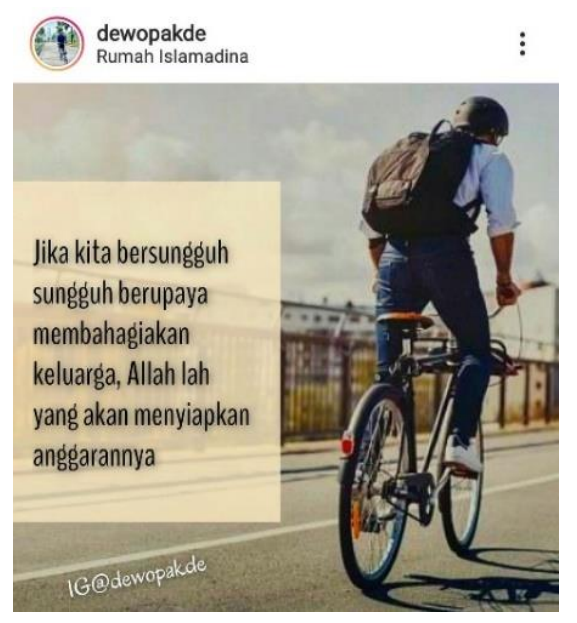

Gambar 4. Wacana Hortatori 4 [17]

Pada gambar 4 tampak adanya pengertian yang menunjukkan motivasi berkaitan dengan niat baik membahagiakan keluarga. Hal ini tampak pada kalimat "Jika kita bersungguhsungguh berupaya membahagiakan keluarga, Allah lah yang akan menyiapkan anggarannya." Artinya, pembaca diingatkan untuk selalu berupaya membahagiakan keluarga. Perasaan yang tampak dari unggahan tersebut adalah perasaan semangat. Nada yang muncul adalah nada penuh optimis, sehingga pembaca yakin bahwa Allah akan memberikan jalan jika ingin membahagiakan keluarga. Adapun tujuan pada unggahan ini berbentuk naratif karena memberikan pandangan yang seolah-olah menceritakan sebuah proses yang harus dilalui.

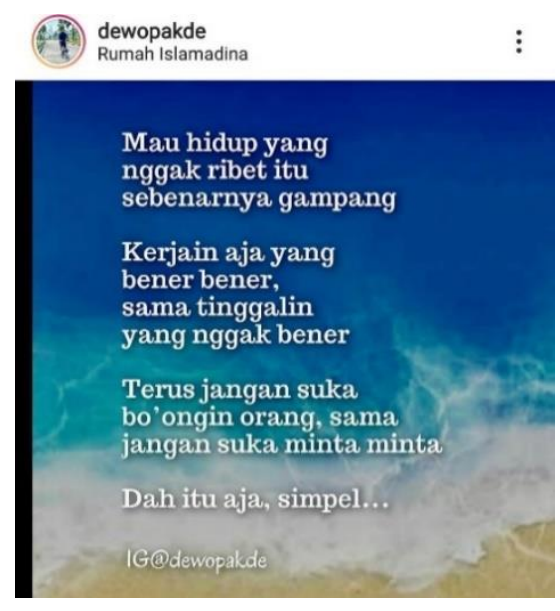

Gambar 5. Wacana Hortatori 5 [17]

Pada gambar 5 tampak adanya pengertian akan sebuah pesan berkaitan dengan cara menjalani kehidupan. Hal ini tampak pada kalimat "Mau hidup yang nggak ribet itu sebenarnya gampang. Kerjakan aja yang bener-bener, sama tinggalin yang nggak bener. Terus jangan suka bohongin orang, sama jangan suka minta-minta. Dah itu aja, simpel." 
Artinya, pembaca diminta untuk hidup sesuai dengan alur dan porsinya. Selalu bersikap jujur dan tidak boleh bermental pengemis (suka meminta-minta). Hal-hal yang dikerjakan pun harus sesuai dengan aturan dan bernilai kebenaran. Perasaan yang tampak dari unggahan tersebut adalah perasaan mengingatkan. Pembaca diingatkan untuk selalu berusaha menjalani hidup dengan penuh semangat dan apa adanya. Nada yang muncul adalah nada santai. Adapun tujuan pada unggahan ini berbentuk persuasif karena mengajak pembaca untuk menjalani kehidupan dengan mudah dan sesuai norma yang ada.

Berdasarkan paparan di atas, tampak bahwa makna di dalam unggahan Instagram @ dewopakde yang dapat dipahami oleh pembacanya meliputi pesan-pesan untuk selalu bersyukur, berpikir positif, bersemangat, bertanggung jawab, dan bermental juang.

\section{Simpulan}

Berdasarkan hasil penelitian, diperoleh pemahaman bahwa terdapat aspek pengertian, perasaan, nada, dan tujuan yang saling berkaitan dalam wacana hortatori yang disampaikan oleh unggahan Instagram @ dewopakde. Dengan demikian, pembaca dapat memahami makna di dalamnya. Unggahan tersebut pun memuat klasifikasi pernyataan yang bersifat persuasif dan naratif, yang dengannya penulis berusaha memengaruhi pembaca untuk mengikuti apa yang disampaikan melalui unggahannya. Kontribusi penelitian ini pada ranah teoretis adalah pembuktian bahwa penggunaan wacana hortatori yang tepat akan sangat efektif untuk memberikan solusi secara verbal atas permasalahan dalam masyarakat. Pada ranah praktis, pelaku media sosial harus mempunyai kompetensi kebahasaan yang baik agar tepat dalam menyampaikan ide dan gagasannya.

\section{Referensi}

[1] Devianty R. Bahasa sebagai cermin kebudayaan. J Tarb 2017;24.

[2] Subagyo BS. Analisis kohesi dan koherensi rubrik tajuk rencana pada surat kabar Solopos dan relevansinya sebagai bahan ajar pembelajaran Bahasa Indonesia di SMA 2011.

[3] Charlina \& Sinaga M. Analisis Wacana. Pekanbaru Cendikia Insa 2006.

[4] Mulyana D. Kajian Wacana: Teori, Metode, dan Aplikasi Prinsip-prinsip Analisis Wacana. Yogyakarta: Tiara Wacana 2005.

[5] Setiyanto E. Wacana Hortatori Ular-Ular Bahasa Jawa: Kajian Slot dan Struktur Slot. Widyaparwa 2012;40:13-24.

[6] Indiyastini T. Paragraf Hortatori dalam Bahasa Jawa: Kajian Unsur-Unsur Pembentuk dan Penandanya. Widyaparwa 2013;41:171-85.

[7] Adinda S, Pangestuti E. Pengaruh Media Sosial Instagram@ Exploremalang Terhadap Minat Berkunjung Followers Ke Suatu Destinasi (Survei Padafollowers@ Exploremalang). J Adm Bisnis 2019;72:176-83.

[8] Kridalaksana H. Kamus Linguistik, Jakarta: PT. Gramedia Pustaka Utama 2001.

[9] Kroger PR. Analyzing meaning: An introduction to semantics and pragmatics (Textbooks in Language Sciences 5). Berlin: Language Science Press; 2018.

[10] Pateda M. Semantik Leksikal. Jakarta: Rineka Cipta; 2001.

[11] Wahyuningsih R, Suryanasari BD, Astuti AP. Analisis Aspek Makna Pada Slogan 
Kabupaten Di Solo Raya. Proceeding of The URECOL 2019:173-9.

[12] Hardiman FB. Seni Memahami: Hermeneutika dari Schleiermacher sampai Gadamer. Jakarta: 2014.

[13] Chaer A. Linguistik Umum Edisi Revisi. Jakarta PT Rineka Cipta 2012.

[14] Chaer A, Muliastuti L. Semantik Bahasa Indonesia. In: Makna dan Semantik. Jakarta: Universitas Terbuka; 2014.

[15] Djajasudarma TF. Semantik 2. Bandung: PT Refika Aditama; 1999.

[16] Palmer FR. Semantics: A New Outline. Cambrige: Cambrige University Press; 1976.

[17] @ dewopakde. Instagram n.d. 